\title{
PERBANDINGAN LATIHAN BAYANGAN DENGAN DRILLING DAN STROKES TERHADAP KECEPATAN REAKSI DAN KETEPATAN SMASH
}

\author{
Gyta Krisdiana Cahyaningrum ${ }^{1}$, Elyana Asnar ${ }^{2}$, dan Tjitra Wardani ${ }^{3}$ \\ ${ }^{1}$ Program Studi Ilmu Kesehatan Olahraga, Universitas Airlangga Surabaya \\ 2,3Program Studi IImu Fisiologi, Universitas Airlangga Surabaya \\ E-mail: 'gyfan.art@gmail.com, ${ }^{2}$ nanaasnar@yahoo.com, \\ 3tjitra2011@gmail.com
}

Diterima: 3 Agustus 2018; Lolos: 27 September 2018; Dipublikasikan: 19 Oktober 2018 DOI: https://doi.org/10.29407/js_unpgri.v4i2.12238

\begin{abstract}
Abstrak
Pukulan smash merupakan salah satu teknik pukulan menyerang dalam permainan bulutangkis. Latihan pengulangan seperti bayangan, drilling dan strokes dapat meningkatkan kecepatan dan koordinasi gerakan. Namun, latihan kombinasi bayangan dengan drilling dan strokes dalam meningkatkan kecepatan reaksi dan ketepatan smash masih belum pernah dijelaskan. Tujuan penelitian ini untuk membuktikan latihan kombinasi bayangan dengan drilling (P1) lebih meningkatkan kecepatan reaksi dan ketepatan smash dibandingkan latihan kombinasi bayangan dengan strokes (P2). Penelitian ini termasuk eksperimental lapangan, subjek 18 orang dibagi secara random menjadi dua kelompok. Kedua kelompok diberi perlakuan 6 minggu dengan frekuensi latihan 4 kali seminggu. Tes kecepatan reaksi menggunakan alat whole body reaction dan tes ketepatan smash menggunakan tes kemampuan ketepatan smash. Hasil uji t berpasangan pada kecepatan reaksi $\mathrm{P} 10,277 \pm 0,08$ dan $\mathrm{P} 2$ 0,270 $\pm 0,629$, ketepatan smash P1 $11,25 \pm 3,732$ dan P2 8,625 $\pm 2,446$, menunjukkan adanya peningkatan kemampuan kecepatan reaksi dan ketepatan smash yang signifikan. Hasil uji t independent perubahan pretest ke posttest pada P1 dan P2 adalah 0,832 dan 0,118 , maka terdapat perbedaan perubahan peningkatan kemampuan yang tidak signifikan. Kesimpulan penelitian ini adalah latihan kombinasi bayangan dengan drilling dan latihan kombinasi bayangan dengan strokes keduanya dapat meningkatkan kemampuan kecepatan reaksi dan ketepatan smash bulutangkis.
\end{abstract}

Kata kunci: bayangan, drilling, strokes, kecepatan reaksi, ketepatan smash.

\section{COMPARISON OF COMBINATION EXERCISE SHADOW WITH DRILLING AND STROKES OF REACTION TIME AND SMASH ACCURACY}

\begin{abstract}
Smash are one of the attacking punch techniques to determine in obtaining the numbers during badminton game. Repetition training methods such as shadows, drilling and strokes can improve speed and coordination of movement, but the exercise has not known the comparison of the increase in reaction time and smash accuracy through a combination exercise of shadow with drilling and strokes exercises. The aim of this study is to prove that the combination of shadow training with drilling (P1) increases the reaction time and smash accuracy
\end{abstract}


more than the comparison combination exercise with strokes (P2). This study included field experimental, with 18 subjects divided randomly into two groups. Both groups were given training for 6 weeks with frequency 4 times a week. Reaction time test using a whole body reaction and smash accuracy using smash accuracy test. Paired t-test result at the reaction time $P 1 \quad 0.277 \pm 0.08$ and $P 2$ $0.270 \pm 0.662$, the smash accuracy of the $P 1$ was $11.25 \pm 3.732$ and $P 2$ $8.625 \pm 2.446$, showed significant increase in reaction time and smash accuracy. The results of independent $t$-test of changes in $P 1$ and $P 2$ are 0.832 and 0.118 , so there is a significant difference in changes in ability to increase. The conclusion of this study is a combination exercises shadow with drilling and combination exercises shadow with strokes can both increase the ability of reaction time and accuracy of badminton smash.

Keywords: shadow, drilling, strokes, reaction time, smash accuracy.

\section{PENDAHULUAN}

Permainan bulutangkis merupakan aktivitas yang memiliki intensitas tinggi dan termasuk permainan dengan gerak yang cepat. Sebagai cabang olahraga prestasi, bulutangkis termasuk olahraga kompetitif yang memerlukan gerakan eksplosif, banyak gerakan berlari, meloncat untuk smash, refleks, kecepatan merubah arah dan juga membutuhkan koordinasi mata-tangan yang baik (Wijaya, 2017). Penentu prestasi pemain bulutangkis selain membutuhkan penguasaan teknik permainan yang baik, apabila tidak dapat melakukan gerakan dengan cepat dan memukul lebih akurat akan sulit memperoleh angka dari lawannya (Icuk \& Kunta, 2002). Presentase kebutuhan teknik pukulan dalam permainan bulutangkis yaitu: a) Servis panjang: 8,65\%; b) Servis pendek: 8,30\%; c) Lob: 34,80\%; d) Smash: 16,83\%; e) Drive: 0,93\%; f) Netting: 20,35\%; g) Dropshot: 10,14\% (Islahuzzaman, 2010). Teknik pukulan bulutangkis yang digunakan sebagai serangan dan untuk menentukan dalam memenangkan poin selama pertandingan adalah pukulan smash (Hamed \& Hassan, 2017). Komponen kondisi fisik yang mempengaruhi kemampuan keterampilan smash diantaranya adalah kecepatan reaksi dan akurasi yang sangat berpengaruh pada kecepatan dan ketajaman smash (Budiwanto, 2013).

Kecepatan reaksi adalah kemampuan suatu respon dari mulai adanya rangsangan sampai timbulnya reaksi gerakan dalam waktu yang 
singkat. Kemampuan gerak dengan cepat setelah menerima rangsangan (dapat berupa pendengaran, penglihatan dan lain-lain) dapat digunakan untuk mencapai tingkat kecepatan optimal gerakan reaksi sebagai gerakan awal yang dapat menunjang gerakan cepat selanjutnya (Ghuntla, Mehta, Gokhale, \& Shah, 2014). Pada permainan bulutangkis membutuhkan komponen kondisi fisik seperti kecepatan reaksi untuk mendukung gerakan yang lebih cepat dalam menjangkau sudut-sudut lapangan dan melakukan pukulan.

Ketepatan adalah kemampuan dalam melakukan suatu gerak ke arah sasaran tertentu sesuai dengan tujuan atau target yang diinginkan. Kemampuan ini dipengaruhi oleh sensitivitas sistem saraf dalam menerima dan memproses stimulus atau rangsangan dari luar, seperti: tepat dalam menilai ruang dan waktu, tepat dalam mendistribusikan tenaga, tepat dalam mengkoordinasikan otot dan sebagainya (Suharno, 1993). Ketepatan suatu keterampilan melibatkan pola gerakan tubuh yang kompleks untuk mencapai tujuan suatu gerakan khusus (Ahmad \& Abdullah, 2014). Pukulan smash pada permainan bulutangkis membutuhkan ketepatan atau akurasi yang bertujuan mengendalikan gerakan dalam memukul kok (shuttlecock) pada arah dan jarak sesuai sasaran atau tujuan (Budiwanto, 2013).

Latihan strokes smash dapat mempengaruhi peningkatan kecepatan smash dalam bulutangkis (Hamed \& Hassan, 2017). Latihan pengulangan gerakan dan skill pukulan melalui metode latihan drilling dapat meningkatkan kekuatan dan mempengaruhi kecepatan smash (Babatunde \& Olusegun, 2014). Latihan dengan melibatkan aspek mengubah arah gerak secara tiba-tiba seperti latihan bayangan (shadow) dapat meningkatkan kelincahan dan koordinasi gerak (Wira Yudha Kusuma, 2015). Untuk mencapai gerakan yang lebih cepat juga diperlukan kemampuan dalam mengantisipasi arah kok (shuttlecock) dengan latihan bayangan secara terprogram, sehingga bertujuan untuk mempercepat gerakan dalam persiapan untuk melakukan pukulan atau pengembalian kok dari lawan baik saat mengejar atau impact (perkenaan 
Gyta Krisdiana Cahyaningrum, Elyana Asnar, dan Tjitra Wardani

Perbandingan Latihan Bayangan dengan Drilling dan Strokes Terhadap Kecepatan Reaksi dan

Ketepatan Smash

kok) (Atsan et al., 2015). Dengan kemampuan mengantisipasi dan ball feeling yang baik dapat mempengaruhi akurasi pukulan sesuai target (Liu et al., 2017).

Metode latihan pengulangan seperti latihan bayangan, drilling dan strokes dapat meningkatkan koordinasi gerakan, kecepatan dan daya tahan otot. Namun proses dari metode latihan yang dapat memberikan stimulus lebih baik pada sistem saraf pusat, saraf sensorik hingga respon saraf motorik yang akan mengaktifkan respon pola fungsi gerakan yang lebih kompleks belum diketahui perbandingan peningkatannya terhadap kecepatan reaksi dan ketepatan pukulan smash melalui latihan kombinasi bayangan dengan drilling smash dan latihan kombinasi bayangan dengan strokes smash.

Penelitian ini diharapkan dapat membuktikan bahwa kecepatan rekasi dan ketepatan smash dapat ditingkatkan melalui latihan bayangan dengan drilling dan strokes.

\section{METODE}

Penelitian ini termasuk eksperimental lapangan dengan menggunakan metode pretest-posttest group design. Penelitian dilaksanakan di Lapangan Bulutangkis Darmoyudo Kota Pasuruan pada bulan Maret - Mei 2018. Subjek dalam penelitian ini adalah peserta ekstrakurikuler bulutangkis di SMA Negeri 4 Pasuruan, berjenis kelamin laki-laki dan berusia 16-18 tahun yang memiliki IMT normal (18,5-22,9 $\mathrm{kg} / \mathrm{m}^{2}$ ) dengan tujuan untuk menyamakan kemampuan fisik serta metabolisme pada setiap subjek dan berdasarkan pentahapan spesialisasi latihan, usia tersebut termasuk dalam tahap pemantapan teknik dan taktik pada cabang olahraga yang diminati (Subardjah, 2000). Penetapan kriteria pada subjek penelitian ini bertujuan untuk mendapatkan data yang homogen dari subjek penelitian.

Besar sampel penelitian dengan menggunakan rumus Lameshow setiap kelompok terdiri dari 9 orang. Besar total subjek penelitian ini sebanyak 18 orang dibagi menjadi dua kelompok, yang terdiri dari 9 orang pada kelompok latihan kombinasi bayangan dengan drilling $(\mathrm{P} 1)$ dan 9 
Gyta Krisdiana Cahyaningrum, Elyana Asnar, dan Tjitra Wardani

Perbandingan Latihan Bayangan dengan Drilling dan Strokes Terhadap Kecepatan Reaksi dan

Ketepatan Smash

orang pada kelompok latihan kombinasi bayangan dengan strokes (P2). Kedua kelompok diberi perlakuan selama 6 minggu dengan frekuensi latihan 4 kali seminggu. Tes kecepatan reaksi menggunakan alat whole body reaction dan pengukuran ketepatan smash menggunakan tes keterampilan smash bulutangkis (PB. PBSI, 2006). Analisis data hasil penelitian menggunakan program IBM SPSS versi 16.0 yang meliputi data statistik sebagai berikut: 1) Uji normalitas dengan menggunakan ShapiroWilk, 2) Uji-t berpasangan (paired t-test), 3) Uji-t independent.

\section{HASIL DAN PEMBAHASAN}

Hasil

Hasil analisis deskriptif pada karakteristik subjek penelitian menunjukkan bahwa rerata umur dari kedua kelompok memiliki kriteria rentang umur yang hampir sama, serta berat badan, tinggi badan dan IMT dari kedua kelompok termasuk dalam kategori normal (18,5-22,9 kg/m2), sehingga sudah memenuhi kriteria pengambilan data.

Tabel 1 Nilai rerata umur, berat badan, tinggi badan dan IMT

\begin{tabular}{ccc}
\hline Variabel & Kelompok P1 $(\mathbf{n}=\mathbf{9})$ & Kelompok P2 $(\mathbf{n}=\mathbf{9})$ \\
\hline Umur (tahun) & $16,25 \pm 0,463$ & $16,38 \pm 0,518$ \\
BB $(\mathrm{kg})$ & $56,13 \pm 2,416$ & $55,25 \pm 7,459$ \\
TB $(\mathrm{m})$ & $1,70 \pm 0,02$ & $1,69 \pm 0,058$ \\
IMT $(\mathrm{kg} / \mathrm{m} 2)$ & $19,36 \pm 0,783$ & $19,26 \pm 1,234$ \\
\hline
\end{tabular}

Data hasil tes kecepatan reaksi dari pre test ke post test terdapat penurunan pada kelompok P1 sebanyak 48,3\% dan P2 44,3\%. Dari penurunan nilai rerata tersebut menunjukkan adanya penurunan nilai rerata pada pencapaian waktu kecepatan reaksi, sehingga terjadi peningkatan kemampuan kecepatan reaksi pada P1 dan P2. Data hasil rerata tes ketepatan smash (pre test ke post test) menunjukkan adanya peningkatan nilai rerata ketepatan smash pada $\mathrm{P} 1$ sebanyak $35,8 \%$ dan P2 30\%. 
Gyta Krisdiana Cahyaningrum, Elyana Asnar, dan Tjitra Wardani

Perbandingan Latihan Bayangan dengan Drilling dan Strokes Terhadap Kecepatan Reaksi dan Ketepatan Smash

Tabel 2. Nilai rerata kecepatan reaksi dan ketepatan smash

\begin{tabular}{cccc}
\hline \multicolumn{2}{c}{ Sumber Data } & Kelompok P1 & Kelompok P2 \\
\hline Kecepatan Reaksi & Pre test & $0,576 \pm 0,08$ & $0,61 \pm 0,72$ \\
(detik) & Post test & $0,298 \pm 0,017$ & $0,34 \pm 0,17$ \\
\hline \multirow{2}{*}{ Ketepatan smash } & Pre test & $20,13 \pm 2,75$ & $20,13 \pm 1,36$ \\
& Post test & $31,38 \pm 1,68$ & $28,75 \pm 1,9$ \\
\hline
\end{tabular}
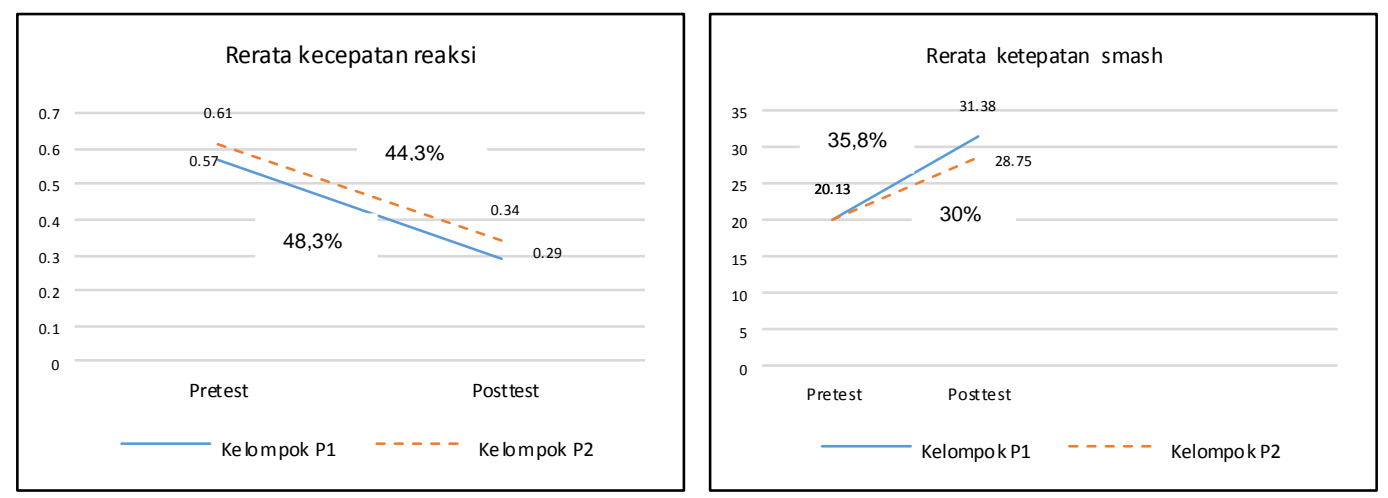

Gambar 1. Grafik rerata kecepatan reaksi dan ketepatan smash

Hasil dari uji normalitas menunjukkan bahwa hasil pre test dan post test pada kecepatan reaksi kelompok P1 adalah 0,062 dan 0,200, sedangkan hasil uji normalitas pada kelompok P2 adalah 0,200 dan 0,060. Pada ketepatan smash kelompok P1 adalah 0,150 dan 0,200, sedangkan pada kelompok P2 adalah 0,193 dan 0,200. Berdasarkan hasil uji normalitas pada kedua kelompok tersebut berdistribusi normal $(p>0,05)$ dan dilakukan uji beda menggunakan statistik parametrik.

Tabel 3. Uji normalitas pada kecepatan reaksi dan ketepatan smash

\begin{tabular}{|c|c|c|c|c|}
\hline \multicolumn{3}{|c|}{ Variabel } & \multirow{2}{*}{$\begin{array}{c}\text { Rerata } \pm \text { SD } \\
0,576 \pm 0,8 \\
0,298 \pm 0,017\end{array}$} & \multirow{2}{*}{$\begin{array}{l}\text { Nilai } p \\
0,062^{*} \\
0,200^{*}\end{array}$} \\
\hline $\begin{array}{l}\text { Kecepatan } \\
\text { reaksi }\end{array}$ & P1 & $\begin{array}{l}\text { Pre test } \\
\text { Post test }\end{array}$ & & \\
\hline $\begin{array}{l}\text { reaksi } \\
\text { (detik) }\end{array}$ & P2 & $\begin{array}{l}\text { Pre test } \\
\text { Post test }\end{array}$ & $\begin{array}{l}0,61 \pm 0,072 \\
0,34 \pm 0,017\end{array}$ & $\begin{array}{l}0,200^{*} \\
0,060^{*}\end{array}$ \\
\hline \multirow{2}{*}{$\begin{array}{c}\text { Ketepatan } \\
\text { smash }\end{array}$} & P1 & $\begin{array}{l}\text { Pre test } \\
\text { Post test }\end{array}$ & $\begin{array}{l}20,13 \pm 2,748 \\
31,38 \pm 1,685\end{array}$ & $\begin{array}{l}0,150^{*} \\
0,200^{*}\end{array}$ \\
\hline & P2 & $\begin{array}{l}\text { Pre test } \\
\text { Post test }\end{array}$ & $\begin{array}{l}20,13 \pm 1,356 \\
28,75 \pm 1,909\end{array}$ & $\begin{array}{l}0,193^{*} \\
0,200^{*}\end{array}$ \\
\hline
\end{tabular}


Gyta Krisdiana Cahyaningrum, Elyana Asnar, dan Tjitra Wardani

Perbandingan Latihan Bayangan dengan Drilling dan Strokes Terhadap Kecepatan Reaksi dan

Ketepatan Smash

Dari hasil uji homogenitas menggunakan uji levene pada kecepatan reaksi adalah 0,768 dan pada ketepatan smash 0,793 , maka dari hasil analisis tersebut dapat dinyatakan bahwa kedua kelompok bersifat homogen ( $p>0,05)$.

Tabel 3. Uji Homogenitas pada Kecepatan Reaksi dan Ketepatan Smash

\begin{tabular}{c|c|c|c|c}
\hline Data & Levene Statistic & df1 & df2 & Sig. \\
\hline Kecepatan reaksi & 0,091 & 1 & 14 & 0,768 \\
\hline Ketepatan smash & 0,071 & 1 & 14 & 0,793 \\
\hline
\end{tabular}

Uji t-berpasangan (Paired $t$-test) bertujuan untuk menganalisis perbedaan antara dua pengamatan. Uji t-berpasangan dilakukan pada subjek yang diuji pada situasi awal sebelum melakukan latihan (pre test) dan pada pasca latihan (post test). Berdasarkan data hasil paired $t$-test pada kelompok P1 (latihan kombinasi bayangan dengan drilling smash) dan kelompok P2 (latihan kombinasi bayangan dengan strokes smash) memperlihatkan hasil nilai $p<0,05$ berarti hipotesis diterima, maka dapat disimpulkan bahwa: Terdapat peningkatan kemampuan kecepatan reaksi dan ketepatan pukulan smash secara bermakna setelah diberikan latihan kombinasi bayangan dengan drilling dan strokes.

Tabel 4. Uji T-Berpasangan Kecepatan Reaksi dan Ketepatan Smash

\begin{tabular}{ccccc}
\hline Kelompok & & Variabel & Rerata \pm SD & Nilai p \\
\hline $\begin{array}{c}\text { Kecepatan reaksi } \\
\text { (detik) }\end{array}$ & P1 & Pre test - Post test & $0,277 \pm 0,08$ & $0,000^{*}$ \\
\hline \multirow{2}{*}{ Ketepatan smash } & Pre test - Post test & $0,270 \pm 0,629$ & $0,000^{*}$ \\
\hline & P1 & Pre test - Post test & $11,25 \pm 3,732$ & $0,000^{*}$ \\
& P2 & Pre test - Post test & $8,625 \pm 2,446$ & $0,000^{*}$ \\
\hline
\end{tabular}

Hasil uji t-independent terhadap kecepatan reaksi dan ketepatan smash sebelum diberikan perlakuan menunjukkan bahwa tidak terdapat perbedaan yang bermakna antara kelompok latihan kombinasi bayangan dengan drilling (P1) dan kelompok latihan kombinasi bayangan dengan strokes (P2) yaitu dengan nilai $p=0,381$ dan $p=1,000 \quad(p>0,05)$ (tabel 5 ). Kondisi demikian memberikan gambaran bahwa kemampuan kecepatan reaksi dan ketepatan smash awal pada kedua kelompok memiliki nilai yang sama (homogen). Dengan demikian, apabila terjadi perbedaan hasil kecepatan reaksi dan ketepatan smash setelah diberikan perlakuan bukan 
Gyta Krisdiana Cahyaningrum, Elyana Asnar, dan Tjitra Wardani

Perbandingan Latihan Bayangan dengan Drilling dan Strokes Terhadap Kecepatan Reaksi dan

Ketepatan Smash

karena kondisi awal yang berbeda melainkan karena adanya pengaruh dari perlakuan yang diberikan pada subjek penelitian.

Tabel 5. Uji t-independent kecepatan reaksi dan ketepatan smash

\begin{tabular}{|c|c|c|c|c|}
\hline & Variabel & & Rerata \pm SD & Nilai $p$ \\
\hline \multirow{2}{*}{$\begin{array}{l}\text { Kecepatan } \\
\text { reaksi } \\
\text { (detik) }\end{array}$} & Pre test & $\begin{array}{l}\text { Kelompok P1 } \\
\text { Kelomnok P2 }\end{array}$ & $\begin{array}{l}0,576 \pm 0,08 \\
0610+007 ?\end{array}$ & 0,381 \\
\hline & Post test & $\begin{array}{l}\text { Kelompok P1 } \\
\text { Kelompok P2 }\end{array}$ & $\begin{array}{l}0,298 \pm 0,017 \\
0,340 \pm 0,017\end{array}$ & $0,000^{*}$ \\
\hline \multirow{2}{*}{$\begin{array}{l}\text { Ketepatan } \\
\text { smash }\end{array}$} & Pre test & $\begin{array}{l}\text { Kelompok P1 } \\
\text { Kelompok P2 }\end{array}$ & $\begin{array}{l}20,13 \pm 2,748 \\
20,13 \pm 1,356\end{array}$ & 1,000 \\
\hline & Post test & $\begin{array}{l}\text { Kelompok P1 } \\
\text { Kelompok P2 }\end{array}$ & $\begin{array}{l}31,38 \pm 1,685 \\
28,75 \pm 1,909\end{array}$ & $0,011^{*}$ \\
\hline
\end{tabular}

Uji t-independent untuk membandingkan perubahan kecepatan reaksi dan ketepatan smash antara kelompok latihan kombinasi bayangan dengan drilling smash dan kelompok latihan kombinasi bayangan dengan strokes smash. Perbedaan tersebut disajikan pada tabel berikut.

Tabel 6. Uji t-independent perubahan kecepatan reaksi dan ketepatan smash

\begin{tabular}{clcc}
\hline & Variabel & Rerata \pm SD & Nilai p \\
\hline $\begin{array}{c}\text { Delta } \\
\begin{array}{c}\text { Kecepatan reaksi } \\
\text { (detik) }\end{array}\end{array}$ & P1 Pre test - P1 Post test & $0,277 \pm 0,08$ & 0 \\
\hline $\begin{array}{c}\text { Delta } \\
\text { Ketepatan smash test - P2 Post test }\end{array}$ & $0,270 \pm 0,06$ & 0,832 \\
& P1 Pre test - P1 Post test & $11,25 \pm 3,73$ & \\
& & 0,118 \\
\hline
\end{tabular}

Pada Tabel. 6 diperoleh hasil dari uji t-independent pada perubahan kecepatan reaksi sebesar 0,832 dan pada perubahan ketepatan smash sebesar 0,118, maka terdapat perbedaan perubahan yang tidak signifikan pada peningkatan kemampuan kecepatan reaksi dan ketepatan smash sebelum dan setelah diberikan perlakuan pada kelompok P1 dan P2 $(p<0,05)$.

\section{Pembahasan}

Metode latihan pengulangan seperti latihan bayangan, drilling dan strokes dapat meningkatkan komponen kondisi fisik khususnya pada daya tahan otot, kecepatan reaksi dan ketepatan yang juga melibatkan 
beberapa faktor, yaitu koordinasi gerakan, ketajaman indera, penguasaan teknik, kecepatan, kekuatan gerakan, keseimbangan dinamis, ketelitian dan ball feeling (Devi, 2017). Latihan dengan metode drilling pada setiap gerakan teknik dapat mempercepat penguasaan keterampilan gerak dan dapat memperkuat koneksi atau kecepatan respon dan mengontrol aspek motoriknya dengan latihan yang terprogram (Chansrisukot, 2015). Latihan strokes merupakan latihan keterampilan pukulan yang dilakukan dengan berpasangan atau saling memberi umpan, serta dilakukan secara berulang dalam serangkaian gerakan (Babatunde \& Olusegun, 2014).

Metode latihan kombinasi bayangan dengan drilling smash perkenaan atau repetisi pengulangan pukulan lebih banyak dibandingkan pada latihan kombinasi bayangan dengan strokes smash. Sehingga dapat diasumsikan bahwa metode latihan kombinasi bayangan dengan drilling smash lebih efisien dapat meningkatkan kemampuan kecepatan reaksi dibandingkan metode latihan kombinasi bayangan dengan strokes smash. Kemampuan kecepatan reaksi yang terjadi merupakan akibat dari adanya stimulus yang di terima oleh reseptor di alirkan melalui saraf eferen sensoris menuju ke sistem saraf pusat (otak), lalu menghasilkan tanda isyarat yang akan dikirim ke efektor. Menjalarnya tanda isyarat dari sistem saraf pusat melalui saraf eferen motorik menuju ke otot skeletal (efektor). Rangsangan isyarat pada otot skeletal menimbulkan kontraksi, gerakan, aktivitas fisik atau kerja (Bańkosz, Nawara, \& Ociepa, 2013).

Kemampuan ketepatan pukulan smash yang terjadi merupakan akibat dari adanya proses latihan yang menyebabkan sistem saraf pusat secara terus-menerus menerima stimulus tentang panjang dan tegangan otot yang diawali dari indera yang terangsang sebagai informasi sensorik yang akan diintegrasikan ke sistem saraf dan menyebabkan respon motorik, sehingga mengaktifkan respon pola fungsi yang lebih kompleks yang tersimpan pada area medula spinalis, batang otak, basal ganglia dan serebelum. Area tersebut akan mengirimkan banyak sinyal pengaktivasian spesifik otot. Akibat dari latihan tersebut akan mengaktivasi lebih banyak neuron dan sinaps pada serebelum yang membantu mengendalikan 
intensitas kontraksi otot dan interaksi sesaat antara kelompok otot agonis dan antagonis, sehingga memiliki kapasitas pengolahan informasi yang sangat besar untuk mengatur keseimbangan dan koordinasi (Kalat, 2012). Latihan yang dilakukan secara berulang-ulang akan mempengaruhi fungsi basal ganglia yang kinerjanya berkaitan dengan sistem kortikospinal pada sirkuit putamen dalam mengatur pola-pola aktivitas motorik yang lebih kompleks dan kinerja pada nukleus kaudatus yang mempengaruhi pengendalian kognitif terhadap pola gerakan motorik yang berurutan (Sherwood, 2016).

Metode latihan bayangan yang dikombinasikan dengan latihan drilling dan latihan kombinasi bayangan dengan strokes tersebut akan meningkatkan sensitivitas saraf sensorik yang mempengaruhi input sensorik yang menuju ke otak dan tersimpan sebagai memori. Hampir semua serabut saraf sensorik dan motorik yang menghubungkan korteks serebri dan medula spinalis berjalan melalui nukleus kaudatus dan putamen. Nukleus kaudatus memainkan peran utama saat menerima sejumlah besar inputnya dari area asosiasi pada korteks serebri, selanjutnya sinyal dikirimkan ke globus palidus internal, lalu ke nuklei pengirim di bagian ventromedial dan ventrolateral talamus, dan akhirnya kembali ke area prefrontal, premotorik dan suplementer korteks serebri, namun hampir tidak ada sinyal yang kembali secara langsung menuju korteks primer tersebut. Sebaliknya, sinyal tersebut kembali berjalan ke regio motorik asesorius di dalam area premotorik dan motorik suplementer (Guyton AC \& Hall JE, 2006). Sehingga reaksi terhadap stimulus tertentu dapat dibuat lebih cepat bahkan otomatis akibat dari latihan berulangulang (drilling) dengan interval istirahat yang cukup, jadi waktu yang diperlukan untuk mereaksi stimulus akan menjadi semakin singkat karena terlatihnya kepekaan saraf sensorik dalam menghantarkan stimulus dan terlatihnya saraf motorik dalam menghantarkan perintah atau sinyal dari otak ke otot (Shelton \& Kumar, 2010). 
Gyta Krisdiana Cahyaningrum, Elyana Asnar, dan Tjitra Wardani

Perbandingan Latihan Bayangan dengan Drilling dan Strokes Terhadap Kecepatan Reaksi dan

Ketepatan Smash

\section{KESIMPULAN}

Metode latihan kombinasi bayangan dengan drilling dan latihan kombinasi bayangan dengan strokes dapat meningkatkan kemampuan kecepatan reaksi dan ketepatan pukulan smash. Pada metode latihan kombinasi bayangan dengan drilling lebih meningkatkan kemampuan kecepatan reaksi dan ketepatan pukulan smash dibandingkan dengan metode latihan kombinasi bayangan dengan strokes, namun terdapat perbedaan perubahan yang tidak signifikan. Kesimpulan dari penelitian ini adalah latihan kombinasi bayangan dengan drilling dan latihan kombinasi bayangan dengan strokes keduanya dapat meningkatkan kemampuan kecepatan reaksi dan ketepatan pukulan smash bulutangkis.

\section{DAFTAR PUSTAKA}

Ahmad, M., \& Abdullah, S. (2014). Effect of Using Different Training Styles on Development of Badmenton Serving Accuracy, XIV(2), 476-480.

Atsan, T., Mizrak, O., Yalmanci, S. G., Eraslan-capan, B., Uygarer, G., Uzunboylu, H., Altun, B. (2015). The anthropologist, 21(3), 527528.

Babatunde \& Olusegun, E. (2014). Effects of Two Methods of Teaching Badminton Strokes on Skill Performance of Children, Journal of Emerging Trends in Educational Research and Policy Studies. 5 (8); 118-123.

Bańkosz, Z., Nawara, H., \& Ociepa, M. (2013). Assessment of simple reaction time in badminton players, 1 (March), 54-61.

Budiwanto, S. (2013). Dasar-Dasar Teknik dan Taktik Bermain Bulutangkis. Malang: Universitas Negeri Malang.

Chansrisukot, G. Suwanthada, S. \& Intiraporn, C. (2015). Cognitive Psychological Training in Combination with Explosive Power Training Can Significantly Enhance Responsiveness of Badminton Players. Journal of Exercise Physiology, 18 (2).

Ghuntla, T. P., Mehta, H. B., Gokhale, P. A., \& Shah, C. J. (2014). Influence of practice on visual reaction time, 19(13).

Guyton AC \& Hall JE, 2006. Guyton \& Hall Textbook of medical physiology, Twelfth edition, Saunders Elsivier, United States of America. 
Hamed, I., \& Hassan, I. (2017). The Effect of Core Stability Training on Dynamic Balance and Smash Stroke Performance in Badminton Players, 2(3), 44-52. https://doi.org/10.11648/j.ijsspe.20170203.12

Icuk, F. \& Kunta, P. (2002). Total badminton. Solo: CV Setyaki Eka Nugraha.

Islahuzzaman, I. (2010). Analisis Teknik Dasar Pukulan Bulutangkis Game 21 pada Tunggal Putra, Jurnal Pendidikan Olahraga dan Kesehatan; 3(1): 295-308.

Kalat, J. W. (2012). Biopsikologi, Biological Physiology. Jakarta: Salemba Humanika.

Kusuma, D. W. Y. (2015). Introducing a New Agility Test in Badminton. American Journal of Sports Science, 3(1), 18. https://doi.org/10.11648/j.ajss.20150301.14

Lauralee, S. (2016). Human Physiology: from Cells to Systems, Ninth edition, Cengage Learning, Canada.

Liu, T., Shao, M., Yin, D., Li, Y., Yang, N., Yin, R., \& Leng, Y. (2017). Neuroscience Letters The e ff ect of badminton training on the ability of same-domain action anticipation for adult novices: Evidence from behavior and ERPs. Neuroscience Letters, 660(May), 6-11. https://doi.org/10.1016/j.neulet.2017.08.038

PB. PBSI. (2006). Buku Pedoman Bulutangkis. Jakarta: PB. PBSI.

Shelton, J., \& Kumar, G. P. (2010). Comparison between Auditory and Visual Simple Reaction Times, 2010(September), 30-32. https://doi.org/10.4236/nm.2010.11004

Subardjah, H. (2000). Bulutangkis. Bandung: Pioner Jaya.

Suharno, H.P. (1993). Metodologi Pelatihan. Jakarta: Pusat Pendidikan dan Penataran Koni.

Suneeta, D. (2017). The Effect of Ball Badminton Game on The Rallying Ability of The Badminton Players At Inter College Level, International Journal of Engineering Sciences \& Research Technology, 6(3).

Wijaya, A. (2017). Analisis Gerak Keterampilan Servis dalam Permainan Bulutangkis (Suatu Tinjauan Anatomi, Fisiologi, dan Biomekanika. Indonesia Performance Journal, 1(2): 106-111. 